\title{
Food Consumption and Iron Intake of Pregnant and Reproductive Aged Women
}

\author{
Ana Paula Sayuri Sato ${ }^{1}$ \\ Elizabeth Fujimori ${ }^{2}$ \\ Sophia Cornbluth Szarfarc ${ }^{3}$ \\ Ana Luiza Vilela Borges ${ }^{4}$ \\ Maria Alice Tsunechiro ${ }^{5}$
}

This study compares the eating habits and consumption of natural and fortified iron sources in pregnant and reproductive aged women. This cross-sectional study was developed in a health center located in São Paulo, SP, Brazil. We studied 61 women, of which 30 were pregnant. A food frequency questionnaire and a 24-hour recall instrument were used. The main natural sources of iron were beans and greens, although fortified foods were also an important source. There was little statistically significant difference between the food consumption of pregnant and non-pregnant women. Inadequate intake of iron, folate and calcium was observed in both groups. Non-pregnant women meet the iron recommendation, considering the iron added in fortified foods, though pregnant women do not. These results suggest the need for mixed strategies: food fortification, iron supplements for pregnant women and nutritional instruction for women in general.

Descriptors: Food Consumption; Iron, Dietary; Women's Health; Prenatal Care.

\footnotetext{
${ }^{1}$ RN, Master's Student, Escola de Enfermagem, Universidade de São Paulo, SP, Brazil. Scholarship holder, Scientific Initiation Program, Pibic/CNPq/USP 2007-2008. E-mail: aps_sato@yahoo.com.br.

${ }^{2}$ RN, Ph.D in Public Health, Associate Professor, Escola de Enfermagem, Universidade de São Paulo, SP, Brazil. E-mail: efujimor@ usp.br.

${ }^{3}$ Chemisty, Ph.D. in Public Health, Associate Professor, Faculdade de Saúde Pública, Universidade de São Paulo, SP, Brazil. E-mail: scfarc@usp.br.

${ }^{4}$ RN, Ph.D. in Public Health, Faculty, Escola de Enfermagem, Universidade de São Paulo, SP, Brazil. E-mail: alvilela@usp.br.

${ }^{5}$ RN, Ph.D. in Nursing, Faculty, Escola de Enfermagem, Universidade de São Paulo, SP, Brazil. E-mail: tamnami@usp.br.
}

Corresponding Author:

Elizabeth Fujimori

Universidade de São Paulo. Escola de Enfermagem

Av. Dr. Enéas de Carvalho Aguiar, 419

Cerqueira César

CEP: 05403-000 São Paulo, SP, Brasil

E-mail: efujimor@usp.br 


\title{
Consumo alimentar e ingestão de ferro de gestantes e mulheres em idade reprodutiva
}

Comparar a prática alimentar e o consumo de alimentos fontes de ferro, naturais e fortificados, de mulheres em idade reprodutiva, gestantes ou não, constituiu o objetivo desta pesquisa. Estudo transversal, desenvolvido em um centro de saúde do município de São Paulo, envolvendo 61 mulheres, sendo 30 gestantes. Utilizou-se questionário de frequência de consumo alimentar e recordatório de $24 \mathrm{~h}$. As principais fontes naturais de ferro foram feijão e folhas verdes. Alimentos fortificados também tiveram participação importante. Houve pequena diferença estatisticamente significativa entre o consumo alimentar das gestantes e não gestantes. Observou-se inadequação do consumo de ferro, folato e cálcio nos dois grupos. As mulheres não gestantes atenderiam a demanda de ferro, considerando-se o adicional recomendado para a fortificação das farinhas, porém, as gestantes não. Há necessidade de estratégias combinadas: fortificação dos alimentos, suplementação medicamentosa para gestantes e orientação nutricional para as mulheres em geral.

Descritores: Consumo de Alimentos; Ferro na Dieta; Saúde da Mulher; Cuidado PréNatal.

\section{Consumo alimentar e ingestión de hierro por mujeres embarazadas y en edad reproductiva}

\begin{abstract}
Comparar la práctica alimentar y el consumo de alimentos fuentes de hierro, naturales y fortificados, de mujeres en edad reproductiva, gestantes o no, constituye el objetivo de esta investigación. Se trata de un estudio transversal, desarrollado en un centro de salud del municipio de Sao Paulo, en el cual participaron 61 mujeres, siendo 30 gestantes. Se utilizó un cuestionario de frecuencia de consumo alimentar y un recordatorio de $24 \mathrm{~h}$. Las principales fuentes naturales de hierro fueron frijoles y hojas verdes. Alimentos fortificados también tuvieron participación importante. Hubo una pequeña diferencia estadísticamente significativa entre el consumo alimentar de las gestantes y no gestantes. Se observó inadecuación del consumo de hierro, folato y calcio en los dos grupos. Las mujeres no gestantes atenderían la demanda de hierro, considerándose el adicional recomendado para la fortificación de las harinas, sin embargo, las gestantes no. Hay necesidad de implementar estrategias combinadas: fortificación de los alimentos, suplemento medicamentoso para gestantes y orientación nutricional para las mujeres en general.
\end{abstract}

Descriptores: Consumo de Alimentos; Hierro en la Dieta; Salud de la Mujer; Atención Prenatal.

\section{Introduction}

Iron deficiency anemia is an important public health problem among pregnant women. Although a global picture of the prevalence of this nutritional deficiency is not available, it is estimated that $52 \%$ of pregnant women in developing countries is anemic (1). In Brazil, the prevalence of anemia is estimated at about 30 to $40 \%$ in pregnant women ${ }^{(2)}$ and $30 \%$ in reproductive aged women ${ }^{(3)}$.
During pregnancy, anemia is harmful both to the woman and child and is associated with a higher risk of maternal and fetal morbidity and mortality ${ }^{(1)}$. Women need to have adequate storage of iron to meet the high requirements of this mineral during the pregnancy. The total iron required during pregnancy is about $1000 \mathrm{mg}$, but the majority of women do not meet this demand(4). One study carried out with adolescent pregnant showed 
that the iron storage was below $300 \mathrm{mg}$ for $32 \%$ of them, and $64 \%$ had less than $500 \mathrm{mg}$ of iron.

This deficiency might occur due to the Brazilians habit of consuming foods with insufficient quantities of iron, based on beans instead of food from animal origin such as red meat and organ meat, the main sources of iron $^{(6-8)}$.

Considering that an inappropriate diet is the main determinant of iron deficiency and also that enriching the foods that compose the diet of Brazilian families contributes to diminishing the risk of iron deficiency, the Brazilian Ministry of Health proposed the Wheat and Corn Flour Fortification with Iron and Folic Acid in 2002(9). Effectively implemented in Brazil in June 2004, the program requires manufacturers to add a minimum of $4.2 \mathrm{mg}$ of iron and $150 \mathrm{mcg}$ of folic acid for each $100 \mathrm{~g}$ of wheat or corn flour produced.

The actions to prevent anemia during pregnancy include not only food fortification but also educating women, so they increase their consumption of iron natural sources and foods that favor the absorption of this mineral, as well as limit their consumption of foods that inhibit iron absorption. This orientation should integrate nursing practice both in the field of obstetrics and that of collective health ${ }^{(10-11)}$.

The relevance of evaluating the eating habits of pregnant and non-pregnant women of reproductive age is justified because it allows the early detection of specific nutritional problems, which can be corrected, avoiding harm during pregnancy. Based on this, the current study compared eating habits and consumption of natural and fortified sources of iron between reproductive aged women, pregnant or not, to provide scientific evidence that can improve the quality of prenatal and women's care.

\section{Method}

This is part of a larger project*, whose objective was to identify the presence of wheat and corn-based foods in the eating habits of pregnant and non-pregnant women of reproductive age. The project was approved by the Ethics Research Committee accredited in the National Council of Research Ethics. This cross-sectional and descriptive study was carried out in one of the health services that compose the sample of São Paulo, SP, Brazil.

The study's population was composed of women between 20 and 49 years of age and pregnant women in at least the $20^{\text {th }}$ week of pregnancy (in order to exclude sickness problems, very common at the beginning of the pregnancy), attending the health unit on Thursdays in the adult and prenatal sectors of a school health center between August and October 2007.

Women were approached in the waiting room and those who signed a free and informed consent form (CEP n0521/2006) participated in the study. Sixty-one women were interviewed: 31 non-pregnant and 30 pregnant women.

A pretested instrument with closed questions was used to identify socioeconomic and demographic data including the following variables: age, schooling, family income, marital status and inclusion in the job market. Weight and height were measured at the time of the interview through a Filizola ${ }^{\circledR}$ anthropometric scale.

Nutritional status was characterized using measures of height and weight to calculate the Body Mass Index (BMI) and according to the indicators proposed by the Brazilian Ministry of Health(12). For pregnant women was used BMI according to week of pregnancy and for nonpregnant women BMI $<18.5$; $\geq 18.5$ and $<25$; $\geq 25$ and $<30$; and $\geq 30$ designated underweight, normal weight overweight and obesity, respectively.

Eating habits were evaluated through a semiquantitative, pretested Food Frequency Questionnaire (FFQ) that included 13 foods in which frequency was characterized as: at least once a day, 2-4 times a day, once a week, 1-3 times a month and rarely/never. The study evaluated the consumption of iron natural sources of animal origin (beef, liver, poultry, fish and eggs) and vegetal origin (bean, greens); fortified foods (bread, crackers and pasta); foods that stimulate iron absorption (fruits/natural juices) and potential inhibitors of iron absorption (coffee/tea, milk/dairy products).

As recommended(13), to better measure food consumption, a 24-hour recall instrument was used concomitantly with the FFQ, which evaluated the food consumption of a one-day period. The intake of energy and nutrients was identified as well as the most frequent composition of daily meals. Adequacy of food consumption was analyzed using the Virtual Nutri(14) software, though Dietary Reference Intakes (DRI) were used as reference values instead of the recommendations included in the program (Recommended Dietary Allowance)(15). The quantity of additional iron and folate present in the fortified foods was estimated considering a daily average consumption of $120 \mathrm{gr}$ of wheat ${ }^{(16)}$, which would have on average $5.1 \mathrm{mg}$ of additional iron and $180 \mathrm{mcg}$ of folic acid, provided the quantities recommended by law are being complied with.

* Part of a larger project funded by the National Counsel of Technological and Scientific Development (CNPq). 
For data analysis purposes, the foods were distributed into three groups of consumption: "frequent", "regular" and "rare". This categorization was based on recommendations of the Food Guide for the Brazilian Population $^{(17)}$. The consumption of cereals (bread, crackers), beans, greens, fruits/juices, meat (beef, poultry and fish) and eggs, milk/dairy and coffee was considered "frequent" if ingested at least once a day, "regular" when ingested 2-4 times a week and "rare" if ingested once a week or less. Pasta and liver were considered of "frequent" consumption if ingested at least once a week, "regular" three times a month and "rare" if rarely or never ingested.

The Statistical Package for Social Sciences (SPSS) version 15.0 and Epi Info version 6.0 were used for the statistical analysis. The Student $t$-test was used to compare average values and the Chi-square test to compare proportions. A level of significance of $5 \%$ was used.

\section{Results}

Both the pregnant and non-pregnant women presented similar socioeconomic, demographic and nutritional characteristics, though, as shown in Table 1 , the pregnant women were younger $(p<0.05)$.

The majority of pregnant women $(67 \%)$ had begun prenatal care in the first quarter and were in the third quarter of pregnancy at the time of the interview (60\%). All of them reported they were receiving and taking iron supplements.
Table 1 - Distribution of non-pregnant $(n=31)$ and pregnant women $(n=30)$ according to socioeconomic, demographic and nutritional characteristics. São Paulo, SP, Brazil 2007

\begin{tabular}{|c|c|c|c|c|c|}
\hline \multirow[t]{2}{*}{ Characteristics } & \multicolumn{2}{|c|}{$\begin{array}{c}\text { Non- } \\
\text { pregnant }\end{array}$} & \multicolumn{2}{|c|}{ Pregnant } & \multirow[t]{2}{*}{$\mathbf{p}$} \\
\hline & $\mathrm{n}$ & $\%$ & $\mathrm{n}$ & $\%$ & \\
\hline \multicolumn{6}{|l|}{ Marital status } \\
\hline Partner & 17 & 54.8 & 18 & 60 & \multirow[t]{2}{*}{$0.881^{\mathrm{a}}$} \\
\hline No partner & 14 & 45.2 & 12 & 40 & \\
\hline \multicolumn{6}{|l|}{ Paid job } \\
\hline Yes & 13 & 41.9 & 15 & 50 & \multirow[t]{2}{*}{$0.707^{\mathrm{a}}$} \\
\hline No & 18 & 58.1 & 15 & 50 & \\
\hline \multicolumn{6}{|l|}{ Nutritional status } \\
\hline Underweight & - & - & 3 & 10 & $0.339^{a}$ \\
\hline Adequate weight & 16 & 51.6 & 15 & 50 & \\
\hline Overweight & 11 & 35.5 & 9 & 30 & \\
\hline Obesity & 4 & 12.9 & 3 & 10 & \\
\hline Average age in years $(S D)$ & \multicolumn{2}{|c|}{$31.6(6.8)$} & \multicolumn{2}{|c|}{$27.1(5.3)$} & $0.005^{b}$ \\
\hline Average schooling in years (SD) & \multicolumn{2}{|c|}{$8.7(3.3)$} & \multicolumn{2}{|c|}{$9.5(3.1)$} & $0.302^{b}$ \\
\hline $\begin{array}{l}\text { Average family income in terms of } \\
M^{c}(S D)^{d}\end{array}$ & \multicolumn{2}{|c|}{$3.0(2.4)$} & \multicolumn{2}{|c|}{$2.8(3.6)$} & $0.857^{\mathrm{b}}$ \\
\hline
\end{tabular}

${ }^{a} \mathrm{p}$-value refers to the Chi-square test; ' Student's t-test; ${ }^{\mathrm{c}} \mathrm{MW}=$ Brazilian monthly minimum wage in 2010 was R\$510, equivalent to US\$287; d Some information was lost.

Table 2 presents the frequency of the food consumption distributed in the three proposed categories and no difference was found between the studied groups. Concerning the most frequent consumed iron natural sources, those of vegetal origin prevailed, especially beans. Meat and eggs were among the most consumed natural iron sources of animal origin.

Table 2 - Percentage of frequency of reported consumption of selected foods according to the group of non-pregnant and pregnant women. São Paulo, SP, Brazil, 2007

\begin{tabular}{|c|c|c|c|c|c|c|c|}
\hline \multirow[t]{2}{*}{ Food } & \multicolumn{3}{|c|}{ Non-pregnant (\%) } & \multicolumn{3}{|c|}{ Pregnant (\%) } & \multirow{2}{*}{$\mathbf{p}^{\mathbf{a}}$} \\
\hline & Frequently & Regularly & Rarely & Frequently & Regularly & Rarely & \\
\hline Meat ${ }^{\mathrm{b}} /$ eggs & 61.3 & 35.5 & 3.2 & 46.7 & 46.7 & 6.6 & 0.487 \\
\hline Organ meat & 22.6 & 25.8 & 51.6 & 26.7 & 40 & 33.3 & 0.327 \\
\hline Beans & 80.6 & 12.9 & 6.5 & 66.7 & 23.3 & 10 & 0.458 \\
\hline Greens & 61.4 & 12.9 & 25.7 & 53.4 & 23.3 & 23.3 & 0.569 \\
\hline Bread & 61.4 & 19.3 & 19.3 & 70 & 26.7 & 3.3 & 0.139 \\
\hline Cracker & 29 & 25.7 & 45.3 & 36.6 & 20 & 43.4 & 0.776 \\
\hline Pasta & 70.9 & 25.8 & 3.2 & 70 & 26.7 & 3.3 & 0.996 \\
\hline Citric fruits & 48.4 & 22.6 & 29 & 63.3 & 20 & 16.7 & 0.432 \\
\hline Coffee & 67.8 & 3.2 & 29.1 & 56.7 & 20 & 23.3 & 0.121 \\
\hline Milk/dairy & 61.4 & 25.7 & 12.9 & 76.7 & 13.4 & 10 & 0.398 \\
\hline
\end{tabular}

${ }^{a} \mathrm{Chi}$-square test between non-pregnant and pregnant women distributed in three categories of frequency.

bIncluded red meat, poultry and fish

Among those foods the main ingredient of which was wheat flour, bread was reported most by the majority of women as a daily-ingested food, as opposed to crackers. Pasta was also part of their diet and was 
frequently consumed by $70 \%$ of the women, that is, at least once a week. There was no report of consumption of corn-based foods (Table 2).

Citric fruits, which improve the absorption of iron, were not consumed daily by all women, though coffee and milk, potential inhibitors of iron absorption, were ingested at least once a day by the majority of the studied women (Table 2).
Around $80 \%$ of the women had dinner and its composition was similar to that of lunch. The distribution of food by meals between the groups was very similar, though, the pregnant women presented a significantly higher $(p<0.05)$ consumption of fruits/natural juices at lunch and afternoon snack, and milk and dairy products at breakfast (Table 3).

Table 3 - Distribution of women according to the most frequently ingested foods in the main daily meals. São Paulo, SP, Brazil 2007

\begin{tabular}{|c|c|c|c|c|c|}
\hline \multirow{2}{*}{ Meal } & \multicolumn{2}{|r|}{ Non-pregnant women } & \multicolumn{2}{|r|}{ Pregnant women } & \multirow{2}{*}{ p value ${ }^{a}$} \\
\hline & n (\%) & n (\%) reported habitual food & n (\%) & n (\%) reported habitual food & \\
\hline Breakfast & $31(100)$ & & $30(100)$ & & \\
\hline Coffee/tea & & $23(74.2)$ & & $22(73.3)$ & 0.829 \\
\hline Bread/cracker (wheat flour) & & $21(67.7)$ & & $26(86.7)$ & 0.146 \\
\hline Milk and dairy products ${ }^{a}$ & & $19(61.3)$ & & $26(86.7)$ & 0.049 \\
\hline Fruits/natural juices & & $8(25.8)$ & & $5(16.7)$ & 0.576 \\
\hline Morning snack & $11(36)$ & & $12(40)$ & & \\
\hline Coffee/tea & & $2(18.2)$ & & $1(8.3)$ & 0.590 \\
\hline Bread/cracker (wheat flour) & & $5(45.4)$ & & $5(41.7)$ & 0.999 \\
\hline Fruits/natural juices & & $7(63.6)$ & & $7(58.3)$ & 0.999 \\
\hline Lunch & $29(94)$ & & $30(100)$ & & \\
\hline Rice & & $26(89.6)$ & & $27(90)$ & 0.999 \\
\hline Beans & & $25(86.2)$ & & $24(80)$ & 0.730 \\
\hline Meats & & $24(82.7)$ & & 28(93.3) & 0.254 \\
\hline Bread/ pasta (wheat flour) & & $5(17.2)$ & & $6(20)$ & 0.950 \\
\hline Salads & & $13(44.8)$ & & 19(63.3) & 0.244 \\
\hline Fruits/natural juices & & $10(34.5)$ & & $24(80)$ & 0.001 \\
\hline Coffee/tea/soft drinks & & $7(24.1)$ & & $2(6.7)$ & 0.079 \\
\hline Afternoon snack & $17(55)$ & & $23(77)$ & & \\
\hline Coffee/tea & & $8(47)$ & & $2(8.7)$ & 0.009 \\
\hline Bread/cracker (wheat flour) & & $10(58.8)$ & & $14(60.8)$ & 0.844 \\
\hline Milk and dairy & & $3(17.6)$ & & $12(52.2)$ & 0.057 \\
\hline Fruits/natural juices & & $4(23.5)$ & & $16(69.5)$ & 0.010 \\
\hline Dinner & $26(84)$ & & $24(80)$ & & \\
\hline Rice & & 18(69.2) & & 19(79.1) & 0.632 \\
\hline Beans & & $15(57.7)$ & & $13(54.1)$ & 0.972 \\
\hline Meats & & $17(65.4)$ & & $20(83.3)$ & 0.261 \\
\hline Bread/pasta (wheat flour) & & $6(23.1)$ & & $2(8.3)$ & 0.250 \\
\hline Salads & & $7(26.9)$ & & $12(50)$ & 0.165 \\
\hline Eggs & & $4(15.4)$ & & $4(16.7)$ & 0.999 \\
\hline Fruits/natural juices & & $2(7.7)$ & & $7(29.1)$ & 0.069 \\
\hline Coffee/tea/soft drink & & $7(26.9)$ & & $3(75)$ & 0.293 \\
\hline Sandwiches & & $3(11.5)$ & & $5(20.8)$ & 0.456 \\
\hline Evening snack & $13(42)$ & & $11(37)$ & & \\
\hline Coffee/tea & & $5(38.4)$ & & $4(36.3)$ & 0.999 \\
\hline Bread/cracker (wheat flour) & & $5(38.4)$ & & $2(18.2)$ & 0.386 \\
\hline Milk and dairy & & $4(30.7)$ & & $4(36.3)$ & 0.999 \\
\hline Fruits/natural juices & & $3(23.1)$ & & $3(27.3)$ & 0.999 \\
\hline
\end{tabular}

${ }^{a}$ Chi-square test between consumption of food between pregnant and non-pregnant women 
Table 4 presents daily-recommended intake, average consumption of selected nutrients and percentage of nutritional adequacy. We verified that the pregnant women presented a significantly higher average consumption of ascorbic acid, folate and calcium $(p<0,05)$. Despite the higher ingestion of calcium among pregnant women, the adequacy level for calcium was low in this group (63\%), though it was significantly higher than among non-pregnant women (48\%). The level of adequacy for folate was very low for both groups (38\%), though with the estimated additional intake, provided the fortification of foods is being carried out as recommended by law, adequacy passes the 50\% mark. Iron presented similar average consumption between groups. Since the recommendation increases by $50 \%$ for pregnant women, even if iron is being added as recommended by law, the percentage of adequacy for this group is significantly lower $(p<0.05)$, about two thirds of the recommended amount.

Table 4 - Daily recommended consumption, average consumption and consumption adequacy of selected nutrients of the studied women. São Paulo, SP, Brazil 2007

\begin{tabular}{|c|c|c|c|c|c|c|c|c|}
\hline \multirow{2}{*}{ Nutrients } & \multicolumn{3}{|c|}{ Non-pregnant } & \multicolumn{3}{|c|}{ Pregnant } & \multirow{2}{*}{$\mathbf{p}^{\mathbf{b}}$} & \multirow{2}{*}{$p^{c}$} \\
\hline & $D R I^{a}$ & Average & Adequacy (\%) & $\mathrm{DRI}^{\mathrm{a}}$ & Average & Adequacy (\%) & & \\
\hline Ascorbic acid (mg) & 75 & 91 & 121 & 85 & 189 & 222 & 0.005 & 0.015 \\
\hline Folate (mcg) & 400 & $154(+180)^{d}$ & $38(84)^{\mathrm{e}}$ & 600 & $229(+180)^{d}$ & $38(68)^{e}$ & 0.003 & 0.96 \\
\hline Calcium (mg) & 1000 & 475 & 48 & 1000 & 633 & 63 & 0.026 & 0.026 \\
\hline Iron (mg) & 18 & $12.4(+5.1)^{d}$ & $69(97)^{\mathrm{e}}$ & 27 & $13.6(+5.1)^{d}$ & $51(69)^{\mathrm{e}}$ & 0.352 & 0.009 \\
\hline
\end{tabular}

a DRI - Dietary Reference Intakes (Institute of Medicine 2004).

b Student t-test of average of consumption of nutrients between non-pregnant and pregnant women

c Student t-test of average of adequacy between non-pregnant and pregnant women

d The values between parentheses represent the additional recommended by law.

e The values between parentheses represent the consumption adequacy, considering the recommended addition.

\section{Discussion}

As part of a larger project, this study compared the eating habits and consumption of natural and fortified sources of iron in pregnant and non-pregnant women in reproductive age attending a public health service of a large city, and, thus, does not allow generalizations. Additionally, the food consumption of a single day was evaluated, which may not represent the individuals' usual consumption $^{(18)}$. However, the 24-hour recall provides detailed information of the types of foods consumed and their quantities. It is worth noting that a food frequency questionnaire was concomitantly applied in order to measure the ingestion of nutrients ${ }^{(13)}$. Another limitation to be mentioned is that the quantity of iron and folate added in fortified foods was estimated considering that the quantities recommended by law and by another study ${ }^{(16)}$ were being complied with.

Iron deficiency anemia is present in all social groups, though it is closely related to poverty, lower educational level and poorer life conditions ${ }^{(2)}$, which is the profile of the majority of women cared for by public health services in Brazil.

It is important to highlight that there are two types of iron in food and they have different bioavailability. The heme iron, found in food of animal origin (muscle tissue, liver, poultry and fish) in the form of hemoglobin and myoglobin is more easily absorbed by the intestinal mucosa. The non-heme iron, found in food of vegetal origin (beans, soy, greens such as kale and spinach) has lower bioavailability and is affected by chemical or food factors $^{(19)}$.

Among the iron natural sources, food of vegetal origin prevailed in the diets of both groups, especially beans. Meat, fish, poultry and eggs were also daily ingested though less frequently, as verified in other studies(7-8,20). The proportion of reported liver consumption of at least once a week is surprising because it is a food rich in heme iron but little consumed by Brazilians. Nevertheless this result is similar to that found by another study carried out with pregnant women ${ }^{(20)}$.

Contrary to what generally is observed in Brazil(21), greens, citric fruits and milk were part of the daily diet of the majority of the studied women. Citric fruits are rich in ascorbic acid and are known for facilitating iron absorption. However, in order to increase the absorption of iron of vegetal origin (non-heme iron) they should to be ingested daily with the main meals: lunch and dinner(19). The frequent presence of fruits/juices in pregnant women's lunch is an indication of good iron absorption, though, the same is not for dinner. Thus, recommending the consumption of citric fruits along 
with the main meals of all women in reproductive age should be reinforced.

In turn, coffee and milk are identified as potential iron absorption inhibitors, but this action is only observed when large quantities of these substances are consumed in the same meal as the iron ${ }^{(19)}$. The high frequency of milk consumption among pregnant women has been verified by other studies ${ }^{(5,7-8,20)}$. However, despite three quarters of pregnant women and two thirds of non-pregnant women reported daily consumption of milk, the percentage of calcium adequacy did not even reach $50 \%$ of the recommended amount for the non-pregnant group.

The iron-fortified foods were clearly present in all women's diets, while bread was ingested daily and pasta was ingested weekly by more than two thirds of women, results that corroborate the findings of other researchers(7-8,16,20-21). A study that evaluated the consumption by pregnant women of food fortified with iron revealed that the most consumed items were bread, crackers, cakes, pasta and couscous ${ }^{(16)}$

It is important to highlight that the consumption of corn was not reported in the 24-hour recall, not as the main ingredient (polenta) or even as an ingredient in cakes and breads. There are probably regional specificities in Brazilian diets, nevertheless, another study carried out in Brasília also found that more than $70 \%$ of the 456 studied pregnant women rarely ingested these foods ${ }^{(16)}$.

Considering an additional $5.1 \mathrm{mg}$ of iron, based on an average consumption of 120 grams/day of wheatbased food(16), provided the law is being complied with, the non-pregnant women reach the daily recommended dose of iron ( $97 \%$ adequacy) but the pregnant women do not (69\% adequacy). However, this study does not analyze the quantity of iron added in wheat, suggesting the need for further studies especially designed to determine that level.

The results revealed that the consumption of iron, not considering the additional fortification of wheat, did not reach the daily-recommended amount, which justifies an iron fortification and supplementation program as well as the concern of researchers and health workers over the consumption of this nutrient by women, especially pregnant women. We stress that other studies obtained the same results in relation to the inadequacy of iron in pregnant women ${ }^{(7-8)}$.

The constant presence of wheat flour byproducts in the daily diet of the interviewed women indicates that these foods are appropriate for being fortified with iron. Another study confirming this fact, however, stresses that attention should be paid to the added quantity and the bioavailability of iron compounds used in the supplementation of these foods ${ }^{(16)}$.

\section{Final considerations}

We observed that non-pregnant women fit into the iron recommendation considering that the minimum quantity of iron recommended by law is really present in the flour fortified with iron. The same was not observed in relation to the pregnant women who, even with the high consumption of natural sources of iron and flour fortified, did not meet the high requirement of iron. This fact corroborates the need for iron supplements during pregnancy.

These results suggest that the Fortification of Wheat and Corn Flours represents an advance in the control of iron deficiency. However, it does not seem to be sufficient to meet daily iron requirements during pregnancy, which reinforces the need for combined strategies: food fortification, iron supplementation and nutritional education.

It should be highlighted the importance of providing nutritional orientation in women's health care, in general, especially to prevent iron deficiency and minimize its risks. The role of health professionals is to inform patients about sources of iron and ways to improve its absorption, clarify concerning the risks of anemia and the importance to take iron supplements during pregnancy.

\section{References}

1. World Health Organization. Iron deficiency anaemia. Assessment, preventing, and control. A guide for programme managers. Geneva; 2001 [Acesso em: 21 novembro 2008]. Disponível em: http://whqlibdoc.who.int/hq/2001/WHO NHD_01.3.pdf

2. Batista M Filho, Souza AI, Bresani CC. Anemia como problema de saúde pública: uma realidade atual. Ciênc Saúde Colet. 2008 novembro/dezembro;13(6):1917-22.

3. Ministério da Saúde (BR). Pesquisa Nacional de Demografia e Saúde da Criança e da Mulher. Relatório Final 2006. Brasília: Ministério da Saúde; 2008.

4. Bothwell $\mathrm{TH}$. Iron requirements in pregnancy and strategies to meet them. Am J Clin Nutr 2000 July; 72(1):257-64.

5. Fujimori E, Laurenti D, Núñez de Cassana LM, Oliveira IMV, Szarfarc SC. Anemia e deficiência de ferro em gestantes adolescentes. Rev Nutr dezembro 2000; 13(3):177-84.

6. Fujimori E, Oliveira IMV, Núnez de Cassana LM, Szarfarc SC. Estado nutricional del hierro de gestantes adolescentes, São 
Paulo, Brasil. Arch Latinoam Nutr março 1999; 49(1):8-12.

7. Azevedo DV, Sampaio HAC. Consumo alimentar de gestantes adolescentes atendidas em serviço de assistência pré-natal. Rev Nutr. julho/setembro 2003; 16(3):273-80.

8. Barros DC, Pereira RA, Gama SGN, Leal MC. O consumo alimentar de gestantes adolescentes no Município do Rio de Janeiro. Cad Saúde Pública. 2004; 20(Supp I):121-9.

9. Ministério da Saúde (BR). Agência Nacional de Vigilância Sanitária. Regulamento Técnico para a Fortificação das Farinhas de Trigo e das Farinhas de Milho com Ferro e Ácido Fólico. Resolução RDC no 344, de 13 de dezembro de 2002. Diário Oficial da União, de 18 de dezembro de 2002. [Acesso em: 15 julho 2008]. Disponível em: http://e-legis.anvisa.gov.br/leisref/ public/showAct. php?id=1679\&word=RDC

10. Engstrom JL, Sittler CP. Nurse-midwifery management of iron-deficiency anemia during pregnancy. J Nurse-Midwifery. 1994 March; 39(Supp 2):20-32.

11. Barros SMO, Costa CAR. Consulta de Enfermagem a gestantes com anemia ferropriva. Rev Latino-am Enfermagem outubro 1999; 7(4):105-11.

12. Ministério da Saúde (BR). Vigilância alimentar e nutricional. Orientações básicas para a coleta, o processamento, a análise de dados e a informação em serviços de saúde. Brasília: Ministério da Saúde; 2004.

13. Bertin RL, Parisenti J, Di Pietro PF, Vasconcelos FAG. Métodos de avaliação do consumo alimentar de gestantes: uma revisão. Rev Bras Saúde Mater Infan. outubro-dezembro 2006; 6(4):383-90.

14. Philippi ST, Szarfarc SC, Latterza AR. Virtual Nutri [computer program], versão1.0, for Windows. São Paulo: Departamento de
Nutrição, Faculdade de Saúde Pública, USP; 1996.

15. Institute of Medicine. Dietary reference intakes. Tables of DRI values. [tabelas na internet]. Washington (DC): National Academy Press; 2004. [Acesso em: 21 julho 2008]. Disponível em: http://www.iom.edu/?id $=54417$

16. Vasconcelos IAL, Cortes MH, Coitinho DC. Alimentos sujeitos à fortificação compulsória com ferro: um estudo com gestantes. Rev Nutr março-abril 2008; 21(2):149-60.

17. Ministério da Saúde (BR). Secretaria de Atenção à Saúde. Coordenação Geral da Política de Alimentação e Nutrição. Guia alimentar para a população brasileira: promovendo a alimentação saudável. Brasília: Ministério da Saúde; 2005. 236p.(Série A. Normas e Manuais Técnicos) [Acesso em: 28 julho 2008]; Disponível em: http://dtr2001.saude.gov.br/editora/produtos/ livros/pdf/05_1109_M.pdf

18. Fisberg RM, Slater $B$, Martini LA. Métodos de inquéritos alimentares. In: Fisberg RM, Slater B, Marchioni DML, Martini LA. Inquéritos alimentares: Métodos e bases científicos. Barueri (SP): Manole; 2005. p. 1-31.

19. Pereira RC, Diniz AS, Ferreira LOC. New findings on iron absorption conditioning factors. Rev Bras Saude Mater Infant outubro-dezembro 2004; 4(3):241-8.

20. Vitolo MR, Boscaini C, Bortolini GA. Baixa escolaridade como fator limitante para o combate à anemia entre gestantes. Rev Bras Ginecol Obstet junho 2006; 28(6):331-9.

21. Fundação IBGE. Pesquisa de orçamentos familiares 20022003. Primeiros resultados. Brasil e Grandes Regiões [documento na internet]. Rio de Janeiro; 2004 [Acesso em: 21 novembro 2008]. Disponível em: http://www.ibge.gov.br/home/estatistica/ populacao/ condicaodevida/pof/2002/pof200220032aed.pdf 